\title{
Bioactive flavone dimers from Ouratea multiflora (Ochnaceae)
}

\author{
Carlos Alberto Carbonezi ${ }^{1}$, Lidilhone Hamerski ${ }^{1}$, A. A. Leslie Gunatilaka ${ }^{2}$, Alberto \\ Cavalheiro $^{1}$, Ian Castro-Gamboa ${ }^{1}$, Dulce Helena Siqueira Silva ${ }^{1}$, Maysa Furlan ${ }^{1}$, \\ Maria Claudia Marx Young ${ }^{3}$, Marcia Nasser Lopes ${ }^{1}$, Vanderlan da Silva Bolzani ${ }^{1 *}$ \\ ${ }^{1}$ Instituto de Química, Universidade Estadual Paulista, UNESP, CP 355, 14801-970, Araraquara, SP, Brazil, \\ ${ }^{2}$ Arid Land Research Institute, University of Arizona, Tucson, AZ 85706-6800, USA, \\ ${ }^{3}$ Seção de Fisiologia e Bioquímica de Plantas, Instituto de Botânica, 01061-970, São Paulo, SP, Brazil
}

\begin{abstract}
RESUMO: "Dímeros flavônicos bioativos de Ouratea multiflora (Ochnaceae)". O fracionamento cromatográfico do extrato orgânico das folhas de Ouratea multiflora forneceu os flavonóides diméricos, heveaflavona, 7",4"'-dimetilamentoflavona, podocarpusflavona-A e amentoflavona. Suas estruturas foram elucidadas com base nos dados espectrais, incluindo experimentos bidimensionais de RMN, das substâncias naturais. A atividade antibiótica de todos os isolados foi avaliada, usando-se as bacterias Gram-positivas Staphylococcus aureus and Bacillus subtilis. Teste de citotoxicidade nas linhagens de linfoma de ratos (L5178) e KB também foram conduzidos para avaliar os extratos e os flavonóides isolados. a triagem biológica para a avaliação de atividade antioxidante e inibidora de acetil colinesterase foram conduzidas pela técnica da bioautografia com DPPH e teste pelo teste de Ellman respectivamente.
\end{abstract}

Unitermos: Ochnaceae, Ouratea multiflora, biflavonoids, antibacterial activity.

\begin{abstract}
Chromatographic fractionation of the organic extract from leaves of Ouratea multiflora afforded the flavone dimers heveaflavone, amentoflavone-7",4"'-dimethyl eter, podocarpusflavone-A and amentoflavone. Their structures were elucidated from spectral data, including 2D-NMR experiments of the natural substances. Biological activities of all isolates were evaluated, using antimicrobial assay against Gram-positive bacteria Staphylococcus aureus and Bacillus subtilis, cytotoxicity assay against mouse lymphoma (L5178) and KB cell lines, TLC screening for acetylcholinesterase inhibitors and antioxidant activity measured by DPPH test.
\end{abstract}

Keywords: Ochnaceae, Ouratea multiflora, biflavonoids, antibacterial activity.

\section{INTRODUCTION}

Species of the Ochnaceae family are distributed in tropical and subtropical zones throughout the World (Hegnauer, 1969; Carvalho et al., 2000) This family is characterized by the presence of flavonoids and biflavonoids and terpenoids as main secondary metabolites (Oliveira et al., 2002; Estevam et al 2005). Several members of the Ouratea genus are employed for the extraction of edible oil, and are used as medicinal plants (Moreira et al., 1994; Agra et al., 2007). As part of our research program on the bioactive constituents of Atlantic Forest plant species, we have investigated Ouratea multiflora collected in Juréia Reserve, São Paulo State. As result, four flavonoid dimers: heveaflavone (Geiger, 1986) amentoflavone-7",4"'-dimethyl-ether (Geiger, 1986), podocarpusflavone-A (Geiger, 1986; Markham et al., 1987) and amentoflavone (Geiger, 1986; Markham et al., 1987; Felício et al., 2001), were isolated from the ethanolic extract of the leaves. Additionally, the biological activity of the isolates was also evaluated.

\section{MATERIAL AND METHODS}

\section{General procedure}

${ }^{1} \mathrm{H}$ and ${ }^{13} \mathrm{C}$ NMR, inverse heteronuclear HMQC and HMBC as well as COSY experiments were performed on a Varian Inova $500 \mathrm{MHz}$ instrument operating at $500 \mathrm{MHz}$ for hydrogen, and $125 \mathrm{MHz}$ for carbon, respectively. Pyridine- $d_{5}$ or DMSO- $d_{6}$ were used as solvents and TMS as internal standard. TLC was performed on precoated aluminum sheets (silica $\mathrm{F}_{254}$, $0.25 \mathrm{~mm}$, Merck, Parmtadt, Germany) with detection provided by UV light ( 254 and $366 \mathrm{~nm}$ ) and by spraying with anisaldeyde reagent followed by heating $\left(120^{\circ} \mathrm{C}\right)$. Silica gel (230-400 mesh ASTM, particle size 0.040$0.063 \mu \mathrm{M}$, Merck) or Sephaex LH-20 (Pharmacia) were used in the $\mathrm{CC}$ fractionations.

\section{Plant material}

Ouratea multiflora was collected at the Botanical reserve of Juréia, São Paulo, Brazil and a 
voucher was placed at the Botanical Institute, São Paulo State, Brazil.

\section{Extraction and isolation}

Dried powdered leaves of Ouratea multiflora $(118.0 \mathrm{~g})$ were extracted by maceration using ethanol at room temperature. The extract was filtered and the solvent was removed under vacuum. The crude extract $(3.44 \mathrm{~g})$ was dissolved in $n$-BuOH. Subsequent addition of water afforded two phases which were evaporated to dryness under reduced pressure. The $n-\mathrm{BuOH}$ fraction $(2.10$ g) was solubilized with methanol/water $(8: 2 \mathrm{v} / \mathrm{v})$ and partitioned with $n$-hexane, chloroform and ethyl acetate, successively. The ethyl acetate phase after concentration of the solvent (980.0 mg), was chromatographed on a Sephadex LH-20 column with a gradient elution of $\mathrm{MeOH} / \mathrm{H}_{2} \mathrm{O}$. The separation was monitored by TLC, and eluted fractions exhibiting similar appearances were combined, yielding 20 fractions. Fractions 7 and 8 showed a solid precipitation. The solid was washed with cold methanol to afford heveaflavone (Geiger, 1986) (1) $(21.2 \mathrm{mg})$. Fraction 13 was chromatographed on silica gel yielding amentoflavone 7", 4"'-dimethyl ether (2) (10.8 mg). Fraction 15 gave a powder after precipitation. This powder was washed with cold methanol to afford podocarpusflavone-A 3 (Markam et al., 1987) (8.9 mg). Fraction 17 was chromatographed on silica gel using $\mathrm{CHCl}_{3}: \mathrm{MeOH}$ (4:6) yielding amentoflavone 4 (Geiger, 1986; Markham et al., 1987) (15.0 mg).

\section{Antimicrobial assay}

Sterile filter paper disks were impregnated with $20 \mathrm{mg}$ of samples using DMSO as carrier solvent. The impregnated disks were then placed on agar plates previously inoculated with Staphylococcus aureus (ATCC 2592) and Bacillus subtilis (DSM 2105). Solvent controls were incubated at $37{ }^{\circ} \mathrm{C}$ for each organism, and after incubate time of $24 \mathrm{~h}$ at $37{ }^{\circ} \mathrm{C}$, antimicrobial activity was recorded as clear zones (in $\mathrm{mm}$ ) of inhibition surrounding the disk. The sample was considered active when the inhibition surrounding the disk was greater than $7 \mathrm{~mm}$.

\section{Cytotoxicity assay}

Antiproliferative activity was examined against two cell lines and was determined through an MTT assay as described earlier (Edrada et al., 1996).

\section{TLC screening for acetylcholinesterase inhibitors}

The protocol adopted for this in vitro assay is described by Ellman and co-workers (Ellman et al., 1961).

\section{Determination of the radical-scavenging activity}

The determination of the antioxidant activity was tested according to a protocol described elsewhere (Cardoso et al., 2004; So; Lewis, 2002).

Table 1. ${ }^{1} \mathrm{H}$ NMR data for compounds $\mathbf{1}, \mathbf{2}, 3$ and 4 (500MHz, DMSO- $d_{6}$ )

\begin{tabular}{|c|c|c|c|c|}
\hline $\mathrm{H}$ & $\mathbf{1}\left(\delta_{\mathrm{H}}, J\right.$ in $\left.\mathrm{Hz}\right)$ & $2\left(\delta_{\mathrm{H}}, J\right.$ in $\left.\mathrm{Hz}\right)$ & $3\left(\delta_{\mathrm{H}}, J\right.$ in $\left.\mathrm{Hz}\right)$ & $4\left(\delta_{\mathrm{H}}, J\right.$ in $\left.\mathrm{Hz}\right)$ \\
\hline 3 & $6.63(\mathrm{~s})$ & $6.82(\mathrm{~s})$ & $6.81(\mathrm{~s})$ & $6.82(\mathrm{~s})$ \\
\hline 6 & $6.23(\mathrm{~d}, 2.5)$ & $6.17(\mathrm{~d}, 2.5)$ & $6.17(\mathrm{~d}, 1.5)$ & $6.18(\mathrm{~d}, 2.5)$ \\
\hline 8 & $6.49(\mathrm{~d}, 2.5)$ & $6.45(\mathrm{~d}, 2.5)$ & $6.45(\mathrm{~d}, 1.5)$ & $6.45(\mathrm{~d}, 2.5)$ \\
\hline 2 ' & $7.82(\mathrm{~d}, 2.5)$ & $7.98(\mathrm{~d}, 2.5)$ & $7.98(\mathrm{~d}, 2.5)$ & $8.00(\mathrm{~d}, 2.5)$ \\
\hline 5 & $7.13(\mathrm{~d}, 9.0)$ & $7.14(\mathrm{~d}, 8.5)$ & $7.15(\mathrm{~d}, 8.5)$ & $7.14(\mathrm{~d}, 9.0)$ \\
\hline 6 ' & $7.86(\mathrm{dd}, 9.0,2.5)$ & $8.01(\mathrm{dd}, 8.5,2.5)$ & $8.00(\mathrm{dd}, 8.5,2.5)$ & $7.99(\mathrm{dd}, 9.0,2.5)$ \\
\hline $3 "$ & $6.67(\mathrm{~s})$ & $6.92(\mathrm{~s})$ & $6.86(\mathrm{~s})$ & $6.78(\mathrm{~s})$ \\
\hline $6 "$ & $6.51(\mathrm{~s})$ & $6.67(\mathrm{~s})$ & $6.41(\mathrm{~s})$ & $6.39(\mathrm{~s})$ \\
\hline $2 ",, 6 "$, & $7.55(\mathrm{~d}, 9.0)$ & $7.66(\mathrm{~d}, 9.5)$ & $7.65(\mathrm{~d}, 9.0)$ & $7.56(\mathrm{~d}, 9.0)$ \\
\hline $3 ",, 5$, & $6.82(\mathrm{~d}, 9.0)$ & $6.91(\mathrm{~d}, 9.5)$ & $6.91(\mathrm{~d}, 9.0)$ & $6.70(\mathrm{~d}, 9.0)$ \\
\hline MeO-4,", & $3.81(\mathrm{~s})$ & $3.83(\mathrm{~s})$ & - & - \\
\hline MeO-7 & $3.77(\mathrm{~s})$ & $3.75(\mathrm{~s})$ & $3.74(\mathrm{~s})$ & - \\
\hline MeO-7', & $3.72(\mathrm{~s})$ & - & - & - \\
\hline OH-5 & $13.93(\mathrm{~s})$ & 12.94 & 13.05 & 13.09 \\
\hline $\mathrm{OH}-5$, & $12.93(\mathrm{~s})$ & 13.20 & 12.95 & 12.96 \\
\hline
\end{tabular}


Table 2. ${ }^{13} \mathrm{C}$ NMR spectral data for compounds $\mathbf{1}, \mathbf{2}, 3$ and 4 (125MHz, DMSO- $\left.d_{6}\right)$

\begin{tabular}{|c|c|c|c|c|}
\hline C & $1(\delta)$ & $2(\delta)$ & $3(\delta)$ & $4(\delta)$ \\
\hline 2 & 163.9 & 163.6 & 163.8 & 163.9 \\
\hline 3 & 103.1 & 103.1 & 103.0 & 102.9 \\
\hline 4 & 181.6 & 181.8 & 181.7 & 181.8 \\
\hline 5 & 162.0 & 161.4 & 161.5 & 162.1 \\
\hline 6 & 97.7 & 98.8 & 98.8 & 98.9 \\
\hline 7 & 164.8 & 164.1 & 164.1 & 164.2 \\
\hline 8 & 92.0 & 94.1 & 94.0 & 94.1 \\
\hline 9 & 157.1 & 157.4 & 157.4 & 157.4 \\
\hline 10 & 104.6 & 103.7 & 103.7 & 103.7 \\
\hline 1, & 120.9 & 121.2 & 121.1 & 120.9 \\
\hline 2 & 130.9 & 131.3 & 131.4 & 131.4 \\
\hline $3^{\prime}$ & 119.4 & 119.6 & 119.9 & 120.1 \\
\hline $4^{\prime}$ & 159.3 & 159.4 & 159.5 & 159.7 \\
\hline 5 & 116.0 & 116.2 & 116.2 & 116.2 \\
\hline $6^{\prime}$ & 127.5 & 128.0 & 127.9 & 127.8 \\
\hline $2 "$ & 163.4 & 163.7 & 163.2 & 163.7 \\
\hline $3 "$ & 102.9 & 103.2 & 103.2 & 102.6 \\
\hline $4 "$ & 182.2 & 182.4 & 182.2 & 182.2 \\
\hline $5 "$ & 161.5 & 161.4 & 160.6 & 161.1 \\
\hline $6 "$ & 95.0 & 95.6 & 98.7 & 98.7 \\
\hline $7 "$ & 161.2 & 162.8 & 161.9 & 160.6 \\
\hline $8 "$ & 104.7 & 105.0 & 104.0 & 104.1 \\
\hline $9 ”$ & 153.6 & 153.7 & 154.5 & 154.5 \\
\hline $10 "$ & 104.2 & 104.2 & 103.7 & 103.6 \\
\hline $1 " ’$ & 122.8 & 122.9 & 123.0 & 121.4 \\
\hline $2^{\prime \prime}$ & 127.6 & 128.1 & 128.0 & 128.2 \\
\hline $3 " ’$ & 114.1 & 114.5 & 114.5 & 115.8 \\
\hline $4 " ”$ & 162.4 & 162.3 & 162.2 & 161.5 \\
\hline $5 " ”$ & 114.1 & 114.5 & 114.5 & 115.8 \\
\hline $6 " ”$ & 127.6 & 128.1 & 128.0 & 128.2 \\
\hline $\mathrm{CH}_{3} \mathrm{O}-4$, & 55.9 & 56.5 & 55.5 & - \\
\hline $\mathrm{CH}_{3} \mathrm{O}-7$ ', & 55.5 & 55.5 & - & - \\
\hline $\mathrm{CH}_{3} \mathrm{O}-7$ & 55.1 & - & - & - \\
\hline
\end{tabular}

\section{RESULTS AND DISCUSSION}

The chromatographic fractionation of the ethanol extract from the leaves of $O$. multiflora afforded heveaflavone (1), amentoflavone-7", 4"'-dimethyl-ether (2), podocarpusflavone-A (3), and amentoflavone (4).
The ${ }^{13} \mathrm{C}$ NMR spectrum of compound 1 showed 31 signals, which were attributed to twelve $\mathrm{sp}^{2} \mathrm{CH}$, including signals at $\delta_{\mathrm{CH}} 114.1$ and 127.6 , each representing two carbon atoms, three $\mathrm{sp}^{3}$ carbons $\left(\delta_{\mathrm{CH} 3}\right.$ 55.1, 55.5 and 55.9), sixteen $\mathrm{sp}^{2}$ quaternary carbons and two carbonyl groups $\left(\delta_{\mathrm{C}} 181.6\right.$ and 182.2) (Table 2). 
The ${ }^{1} \mathrm{H}$ NMR spectrum showed signals for two chelated hydroxyls at $\delta_{\mathrm{H}} 13.19$ and 12.93 (OH-5 and OH-5"), three aromatic methoxyl groups, a 1,3,4-trisubstituted aromatic ring (B ring) and a 1,4-disubstituted ( $\mathrm{B}^{\prime}$ ring). The ${ }^{1} \mathrm{HNMR}$ spectra [1D and 2D $\left.\left({ }^{1} \mathrm{H}-{ }^{1} \mathrm{H}-\mathrm{COSY}\right)\right]$ showed a para-substituted aromatic ring at $\delta_{\mathrm{H}} 7.55(\mathrm{~d}, J 9.0 \mathrm{~Hz}$, H-2", H-6"'), $\delta_{\mathrm{H}} 6.82$ (d, J $9.0 \mathrm{~Hz}, \mathrm{H}-3$ "', H-5"'), two meta aromatic hydrogens at $\delta_{\mathrm{H}} 6.23(\mathrm{~d}, J 2.5 \mathrm{~Hz}, \mathrm{H}-6)$, $6.49(\mathrm{~d}, J 2.5 \mathrm{~Hz}, \mathrm{H}-8)$, commonly observed in a flavone nucleous. The structure of 1 was established on the basisi of HMBC spectra, which showed heteronuclear longrange couplings of quaternary carbons C-7" $\left(\delta_{\mathrm{C}} 161.2\right)$, C-7 $\left(\delta_{\mathrm{C}} 164.8\right)$ and C-4"' $\left(\delta_{\mathrm{C}} 162.4\right)$ with the hydrogens of methoxyl groups at $\delta_{\mathrm{H}} 3.72$ (OMe-7"), 3.77 (OMe-7), and 3.81 (OMe-4"'), respectively, and by comparison of their spectral data with those reported for heveaflavone (Geiger, 1986).

Compound 2 also showed spectral features of a flavonoid dimer derivative (Table 2). The ${ }^{1} \mathrm{H}$ MNR spectrum (Table 1) of 2 showed the presence of to chelated hydroxyl and at $\delta_{\mathrm{H}} 3.83$ and $\delta_{\mathrm{H}} 3.75$ two methoxyl groups. The ${ }^{1} \mathrm{H}-{ }^{1} \mathrm{H}-\mathrm{COSY}$ spectrum of compound 2 showed a set of doublets at $\delta_{\mathrm{H}} 7.66(\mathrm{~d}, J 9.5$ $\mathrm{Hz}, \mathrm{H}-2$ "', H-6"') and $\delta_{\mathrm{H}} 6.91$ (d, J9.5 Hz, H-3"', H-5"') of an AA'BB' system, besides the signals at $\delta_{\mathrm{H}} 7.98(\mathrm{~d}$, $J 2.5 \mathrm{~Hz}, \mathrm{H}-2^{\prime}$ ), 7.14 (d, $J 8.5, \mathrm{H}-5^{\prime}$ ') and 8.01 (dd, $J 8.5$; 2.5, H-6') attributed to a 1,3,4-trisubstituted aromatic ring. Furthermore, the ${ }^{1} \mathrm{H}-{ }^{1} \mathrm{H}-\mathrm{COSY}$ spectrum showed signals with a meta coupling pattern at $\delta_{\mathrm{H}} 6.17(\mathrm{~d}, J$ $2.5 \mathrm{~Hz}, \mathrm{H}-6)$ and 6.45 (d, J 2.5 Hz, H-8) corresponding to an A ring of a flavone. The HMBC spectrum of 2 revealed correlations of the hydrogen-bonded $\mathrm{OH}-5\left(\delta_{\mathrm{H}}\right.$ $12.94)$ with $\mathrm{C}-5\left(\delta_{\mathrm{C}} 161.4\right), \mathrm{C}-6\left(\delta_{\mathrm{C}} 98.8\right)$ and $\mathrm{C}-10\left(\delta_{\mathrm{C}}\right.$ $103.7)$, while $\mathrm{OH}-5$ " $\left(\delta_{\mathrm{H}} 13.20\right)$ correlated with $\mathrm{C}-5$ " $\left(\delta_{\mathrm{C}}\right.$ $161.4), C-6 "\left(\delta_{C} 95.6\right)$ and C-10" $\left(\delta_{C} 104.2\right)$. From the long range coupling of H-6 $\left(\delta_{\mathrm{H}} 6.17\right)$ and $\mathrm{H}-3\left(\delta_{\mathrm{H}} 6.82\right)$ with C-10 $\left(\delta_{\mathrm{C}} 103.7\right)$; H-3"' and H-5"' $\left(\delta_{\mathrm{H}} 6.91\right)$ with C1 "' $\left(\delta_{\mathrm{C}} 122.9\right)$; and H-3" $\left(\delta_{\mathrm{H}} 6.92\right)$ with $\mathrm{C}-10$ " $\left(\delta_{\mathrm{C}} 104.2\right)$ thus, the structure of $\mathbf{2}$ was established to be a dimer. A literature search confirmed the structure of 2 as 7",4"'dimethoxy-amentoflavone (Geiger, 1986).

${ }^{1} \mathrm{H}$ and ${ }^{13} \mathrm{C}$ NMR spectra of $\mathbf{3}$ showed signals at $\delta_{\mathrm{H}}$ $13.05, \delta_{\mathrm{C}} 182.2, \delta_{\mathrm{H}} 12.95$, and $\delta_{\mathrm{C}} 181.8$ of two hydrogen of chelated hydroxyl groups, and an $O$-methyl group at $\delta_{\mathrm{H}} 3.74\left(\delta_{\mathrm{C}}\right.$ 55.5). A detailed analysis of cross peaks from the ${ }^{1} \mathrm{H}-{ }^{1} \mathrm{H}$ COSY spectrum showed two doublets for a mono-oxygenated para disubstituted system at $\delta_{\mathrm{H}} 7.65$ (d, J 9.0 Hz, H-2"', H-6"') and 6.91 (d, J 9.0 $\mathrm{Hz}, \mathrm{H}-3$ "', H-5"'), one trioxygenated tetra substituted ring with alternating oxy-substituents at $\delta_{\mathrm{H}} 6.17(\mathrm{~d}, J$ $1.5 \mathrm{~Hz}, \mathrm{H}-6)$ and $\delta_{\mathrm{H}} 6.45(\mathrm{~d}, J 1.5 \mathrm{~Hz}, \mathrm{H}-8)$, and one mono-oxygenated trisubstituted system at $\delta_{\mathrm{H}} 7.98(\mathrm{~d}, J$ $2.5 \mathrm{~Hz}, \mathrm{H}-2^{\prime}$ ), 7.15 (d, $J 8.5 \mathrm{~Hz}, \mathrm{H}-5^{\prime}$ ') and 8.00 (dd, $J$ 8.5; $2.5 \mathrm{~Hz}, \mathrm{H}-6$ '). Additional $1 \mathrm{D}$ and $2 \mathrm{D}$ NMR data indicated a pentasubstituted aromatic ring with a 5,7dioxygenation pattern for the $A^{\prime}$ ring of a flavone $\left(\delta_{\mathrm{H}}\right.$ $6.41, \mathrm{H}-6$ ") and two singlets $\left(\delta_{\mathrm{H}} 6.81(\mathrm{H}-3), \delta_{\mathrm{H}} 6.86\right.$

(H-3") of both flavones units in compound 3. Analysis of HMBC spectra revealed characteristic correlations which defined the positions of aromatic rings and their substitution patterns. Correlations of H-3 $(\delta 6.81)$ with C-2 $(\delta$ 163.8), C-4 ( $\delta$ 181.7), C-10 ( $\delta$ 103.7), C-1' $(\delta$ $121.1)$ and $\mathrm{H}-3 "(\delta$ 6.86) with $\mathrm{C}-2$ " $(\delta$ 163.2), C-4" $(\delta$ $182.2), C-10 "(\delta$ 103.7), C-1" " $(\delta 123.0)$ established the linkages between rings $\mathrm{C} / \mathrm{B}$ and $\mathrm{C}$ "/B", respectively. Moreover, the correlation between $\mathrm{H}-2$ ' $(\delta 7.98)$ and $\mathrm{C}$ 8 " ( $\delta$ 104.0) showed the linkage between C-3'and C-8". The ROESY correlation observed between methoxyl group at $\delta_{\mathrm{H}} 3.74$ and the aromatic protons at $\delta_{\mathrm{H}} 6.91(\mathrm{~d}, J$ $9.0 \mathrm{~Hz}, \mathrm{H}-3$ "', H-5"') justify the location of the methoxyl group at C-4"' of the B' aromatic ring. These data are in agreement with those published for podocarpusflavoneA (Geiger, 1986; Markham, et al., 1987).

${ }^{1} \mathrm{H}$ NMR spectrum of 4 showed two signals at $\delta_{\mathrm{H}}$ 13.09 and 12.96 due to chelated phenolic hydroxyls, and two doublets at $\delta_{\mathrm{H}} 7.56(J 9.0 \mathrm{~Hz}, \mathrm{H}-2 ",, \mathrm{H}-6 " ')$, and $6.70(J 9.0 \mathrm{~Hz}, \mathrm{H}-3$ "', H-5"') assigned to an AA'BB' aromatic system. Signals of a trisubstituted aromatic ring containing one oxygenated carbon were observed at $\delta_{\mathrm{H}} 8.00\left(\mathrm{~d}, J 2.5 \mathrm{~Hz}, \mathrm{H}-2^{\prime}\right), 7.14$ (d, J 9.0 Hz, H-5'), and 7.99 (dd, $J 9.0 ; 2.5 \mathrm{~Hz}$ H-6'), along with doublets of a tetrasubstituted aromatic ring containing three oxygenated carbons at $\delta_{\mathrm{H}} 6.18(J 2.5 \mathrm{~Hz}, \mathrm{H}-6)$ and $6.45(J 2.5 \mathrm{~Hz}, \mathrm{H}-8)$. Analysis of the HMBC spectra evidenced correlations of the hydroxyl group with hydrogen bonded by cross peak at $\delta_{\mathrm{H}} 13.09(\mathrm{OH}-5)$ with C-5" ( $\delta$ 161.1), C-6" ( $\delta$ 98.7), and C-10" ( $\delta$ 103.6) and $\delta_{\mathrm{H}} 12.96(\mathrm{OH}-5 ")$ with $\mathrm{C}-5(\delta$ 162.1), C-6 ( $\delta$ 98.9) and $\mathrm{C}-10(\delta 103.7)$, which are in agreement to those of amentoflavone (Geiger, 1986; Markham et al., 1987).

Previous studies on ${ }^{13} \mathrm{C}$ NMR data for amenthoflavone derivative dimers indicated a close relationshipbetween substituenteffects and chemical shift for the inter-flavonoid linkage: a) amenthoflavones; I-3' (+6 ppm), II-8" (+ $10 \mathrm{ppm}), \mathrm{b})$ dihydroamenthoflavone; I-3'(+ 4 ppm), II-8" (+9 ppm), which can be diagnostic values in the recognition of new biflavones in the amenthoflavone series (Markhan, et al., 1987; Felício, et al., 2001). The values of ${ }^{13} \mathrm{C}$ NMR spectra of 1-4 (Table 2) followed logically the average found to the series reported and indicated that $O$-methylation induced shifts that are in the same direction as those reported for monoflavonoids (Markham, 1978).

The biflavonoids were assayed for cytotoxicity toward mouse lymphoma (L5178) and melanoma cancer cell line (KB) (Edrada et al., 1996). None of the compounds were active toward the cell line, however, they showed weak activity against the Gram-positive bacteria $S$. aureus and $B$. subitilis at the concentrations of 0.5 and $10 \mu \mathrm{g} / \mathrm{mL}$ (Table 3). The reference antibiotic, streptomycin sulfate, inhibited the growth of all bacterial species tested in this study at $5 \mu \mathrm{g} / \mathrm{mL}$ (zone inhibition $=30-35 \mathrm{~mm}$ ). Compounds 1-4 also were submitted to preliminary TLC screening for selecting potential 
Table 3. Biological activity of compounds 1-4.

\begin{tabular}{|c|c|c|c|c|c|}
\hline \multirow[t]{3}{*}{ compound } & \multicolumn{4}{|c|}{ zone inhibition $(\mathrm{mm})$ for the agar plate diffusion assay } & \multirow{3}{*}{$\begin{array}{l}\text { scavenging activity assay for the } \\
\text { DPPH radical } \\
\mathrm{IC}_{50}(\mu \mathrm{M})^{\mathrm{b}}\end{array}$} \\
\hline & \multicolumn{2}{|c|}{ S. aureus } & \multicolumn{2}{|c|}{ B. subtilis } & \\
\hline & $5 \mu \mathrm{g} / \mathrm{mL}$ & $10 \mu \mathrm{g} / \mathrm{mL}$ & $5 \mu \mathrm{g} / \mathrm{mL}$ & $10 \mu \mathrm{g} / \mathrm{mL}$ & \\
\hline 1 & 7 & 10 & 7 & 12 & 50.0 \\
\hline 2 & n.a & 10 & 7 & 10 & 40.7 \\
\hline 3 & 7 & 9 & 7 & 12 & 35.4 \\
\hline 4 & n. $\mathrm{a}^{\mathrm{a}}$ & 9 & 9 & 12 & 18.5 \\
\hline streptomycin $^{\mathrm{c}}$ & 30 & 32 & 22 & 35 & - \\
\hline rutin $^{c}$ & - & - & - & - & 12 \\
\hline
\end{tabular}

${ }^{\mathrm{a}} \mathrm{n} . \mathrm{a}$ (not active). ${ }^{\mathrm{b}}$ Concentration in $\mu \mathrm{M}$ required to scavenge $50 \% \mathrm{DPPH}$ free radical. ${ }^{\mathrm{c} S t r e p t o m y c i n}$ sulfate and rutin

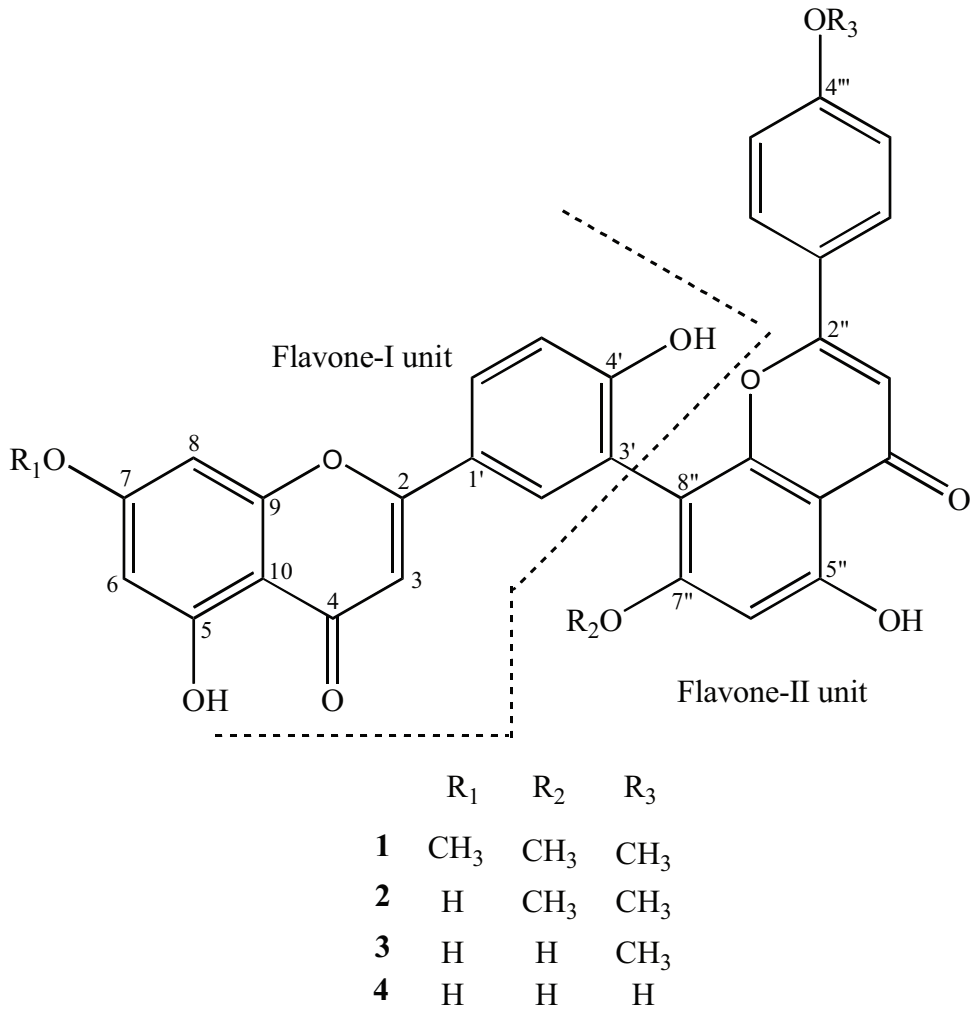


acetylcholinesterae (AchE) inhibitors (Ellman et al., 1961), in which none inhibited the enzyme at 0.1 and $1.0 \mu \mathrm{M}$ concentrations. The antioxidant activities of biflavones 1-4 were tested toward DPPH radical (Table 3) (Cardoso et al. 2004). Compound 4 showed moderate scavenging activity $\left(\mathrm{IC}_{50} 18.5 \mu \mathrm{g} / \mathrm{mL}\right)$ in this test (So; Lewis, 2002), while 1-3 showed weak scavenging activity which confirms the dependence of antioxidant activity with the number of free aromatic hydroxyl groups of tested compounds.

\section{ACKNOWLEDGMENT}

This work was funded by grants of the Fundação de Amparo à Pesquisa do Estado de São Paulo (FAPESP) as part of the Biota-FAPESP - The Biodiversity Virtual Institute Program (www.biotasp.org.br), grant $\mathrm{n}^{\circ}$ 03/02176-7 awarded to V. da S. Bolzani, Principal Investigator. V. da S. B., M.F. and C.A.C acknowledge CNPq and CAPES for researcher and Ph.D. fellowships. The authors wish to thank Arid Land Research Institute University of Arizona (Tucson, USA) by complementation of the fellowship awarded to C.A.C .

\section{REFERENCES}

Agra MF, França PF, Barbosa-Filho JM 2007. Synopsis of the plants known as medicinal and poisonous in Northeast of Brazil. Rev Bras Farmacogn 17: 114140.

Cardoso CL, Castro-Gamboa I, Silva DHS, Furlan M, Epifanio RA, Pinto AC, Rezende CM, Lima JAL, Bolzani VS 2004. Indole glucoalkaloids from Chimarrhis turbinata and their evaluation as antioxidant agents and acetylcholinesterase inhibitors. J Nat Prod 67: 1882-1885.

Carvalho MG, Carvalho GJA, Braz-Filho R 2000. Chemical constituents from Ouratea floribunda: complete ${ }^{1} \mathrm{H}$ and ${ }^{13} \mathrm{C}$ RMN assignments of atranorin and its new acetylated derivative. J Braz Chem Soc 11: 143-147.

Edrada RA, Proksch P, Wray V, Witte L, Müller WEG, Van Soest RWM 1996. Four new bioactive manzaminetype alkaloids from the Philippine marine sponge Xestospongia ashmorica. J Nat Prod 59: 1056-1060.

Ellman GL, Courtney KD, Andres V, Featherstone RM 1961. A new and rapid colorimetric determination of acetylcholinesterase activity. Biochem Pharmacol 7: 88-90.

Estevam CS, Oliveira FM, Conserva LM, Lima LF, Barros ECP, Barros SCP, Rocha EMM, Andrade EHA 2005. Constituintes químicos e avaliação preliminar in vivo da atividade antimalárica de Ouratea nitida Aubl (Ochnaceae). Rev Bras Farmacogn 15: 195-198.

Felicio JD, Rossi MH, Park HR, Gonçalez E, Braggio MM, David JM, Cordeiro I 2001. Biflavonoids from Ouratea multiflora. Fitoterapia 72: 453-455.

Geiger H 1986. The Flavonoids: Advances in Research since 1986. London Chapman and Hall.

Hegnauer R 1969. Chemotaxonomie der Pflanzen, Vol. V. Basel: Stuttgart.
Markham KR, Ternai B, Stanley R, Geiger H, Mabry TR 1978. ${ }^{13} \mathrm{C}$ NMR studies of flavonoids 3 naturally occurring flavonoid glycosides and their acylated derivatives. Tetrahedron 34: 1389-1397.

Markham KR, Sheppard C, Geiger H 1987. ${ }^{13} \mathrm{C}$ NMR of flavonoids $4{ }^{13} \mathrm{C}$ NMR studies of some naturally occurring amentoflavone and hinokiflavone biflavonoids. Phytochemistry 26: 3335-3337.

Moreira IC, Sobrinho DC, Carvalho MG, Braz-Filho R 1994. Isoflavone dimers hexaspermone-A, hexaspermone$\mathrm{B}$ and hexaspermone-C from Ouratea hexasperma. Phytochemistry 35: 1567-1572.

Oliveira MCC, Carvalho MG, Silva CJ, Werle AA 2002. New biflavonoid and other constituents from Luxemburgia nobilis EICHL. J Braz Chem Soc 13: 119-123.

So S, Lewis BA2002. Free radical scavenging and antioxidative activity of caffeic acid amide and ester analogues: Structure-activity relationship. J Agric Food Chem 50: 468-472. 